\title{
Use of a Pulsed Electric Field to Improve the Biogas Potential of Maize Silage
}

\author{
Dawid Szwarc*(D) and Karolina Szwarc \\ Department of Environmental Engineering, Faculty of Geoengineering, University of Warmia and Mazury, \\ 10-720 Olsztyn, Poland; karolina.kupczyk@uwm.edu.pl \\ * Correspondence: dawid.szwarc@uwm.edu.pl
}

check for

updates

Citation: Szwarc, D.; Szwarc, K. Use of a Pulsed Electric Field to Improve the Biogas Potential of Maize Silage. Energies 2021, 14, 119. https://doi.org/10.3390/en14010119

Received: 15 October 2020

Accepted: 18 December 2020

Published: 28 December 2020

Publisher's Note: MDPI stays neutral with regard to jurisdictional claims in published maps and institutional affiliations.

Copyright: (c) 2020 by the authors. Licensee MDPI, Basel, Switzerland. This article is an open access article distributed under the terms and conditions of the Creative Commons Attribution (CC BY) license (https: / / creativecommons.org/ licenses/by/4.0/).

\begin{abstract}
Some types of biomass require great inputs to guarantee high conversion rates to methane. The complex structure of lignocellulose impedes its penetration by cellulolytic enzymes, as a result of which a longer retention time is necessary to increase the availability of nutrients. To use the full biogas potential of lignocellulosic substrates, a substrate pretreatment is necessary before the proper methane fermentation. This article discusses the impact of the pretreatment of maize silage with a pulsed electric field on biogas productivity. The experiment showed a slight decrease in cellulose, hemicellulose and lignin content in the substrate following pretreatment with a pulsed electric field, which resulted in a higher carbohydrate content in the liquid substrate fraction. The highest biogas production output was obtained for the pretreated sample at the retention time of $180 \mathrm{~s}$ for $751.97 \mathrm{~mL} / \mathrm{g}$ volatile solids (VS), which was approximately $14 \%$ higher than for the control sample. The methane production rate for the control sample was $401.83 \mathrm{~mL} \mathrm{CH}_{4} / \mathrm{g} \mathrm{VS}$, and for the sample following disintegration it was $465.62 \mathrm{~mL} \mathrm{CH}_{4} / \mathrm{g}$ VS. The study found that pretreatment of maize silage with a pulsed electric field increased the biogas potential.
\end{abstract}

Keywords: PEF; biogas; lignocellulose; anaerobic digestion; pulsed electric field; methane fermentation

\section{Introduction}

The global energy demand continues to grow, and reserves of non-renewable fossil fuels have been depleting through continuous exploitation. Due to the strict limitations of carbon dioxide emissions, interest in the production of fuels from biomass has been increasing in many countries [1]. Growing public awareness and concern for the environment have stimulated the search for alternative, environmentally friendly, and most importantly, renewable energy sources of low toxicity to the environment. However, biofuel production consumes large amounts of raw materials that can be used in food production. This adverse economic and social phenomenon, therefore, has encouraged scientists to search for alternative solutions that use waste materials. In terms of availability and quantity, waste containing lignocellulose complex is the most common raw material. This biomass is considered to be the most common source of carbon on earth [2]. Due to its availability throughout the year and its potential for renewal, this biomass has gained great attention in the scientific community. Sources of lignocellulosic biomass include forest residues, agricultural residues, energy crops and cellulose waste. In recent years, there has been a trend toward the development of new technologies which use lignocellulosic waste for energy production. The use of these raw materials is associated with the need to solve several problems resulting from the complicated structure of the lignocellulosic complex, which makes it difficult for cellulolytic enzymes to penetrate the raw material.

The cell walls of most plants are made of about $40-60 \%$ cellulose, $15-30 \%$ hemicellulose, about 10-25\% lignin, as well as extractable compounds and inorganic matter. The content of individual components varies depending on the type of biomass [3-5].

One of the methods for the production of renewable energy is the conversion of lignocellulosic biomass to biogas in methane fermentation, but this process requires multi-stage 
processing. Due to the structure of lignocellulosic biomass, it is not fully utilized and has a low conversion rate. The main way to solve this problem is to use pretreatment to break hydrogen bonds in hemicellulose and lignin and to reduce the degree of polymerization and crystallinity of cellulose. All of these treatments aim at increasing the degree of degradation and availability by loosening the biomass structures.

Pretreatment is an important process in obtaining cellulose from biomass and in breaking down the lignin barrier. Effective pretreatment should strive to achieve maximum efficiency with minimum energy input while keeping operating costs low.

Electrotechnology is an innovative branch of bioprocessing technologies, which has been developing rapidly and consists of using an electric current. An external electric field (EF) is used to support and intensify processes such as separation, extraction, drying, and disintegration [6].

Pulsed electric field technology (PEF) is one of the ways of pretreating lignocellulose material. It is a non-thermal processing technique that uses high voltage amplitude electric waves. PEF involves using electric impulses with a high electric field strength of 0.1 up to $200 \mathrm{kV} / \mathrm{cm}$ of short duration (<1 s, nano-seconds, or micro-seconds), with the prime aim of inducing electroporation $[7,8]$. The range of electric field strength used depends on the size of the cells and the purpose of the pretreatment. The strength of $0.5-1.5 \mathrm{kV} / \mathrm{cm}$ is applied to the induction of stress responses and reversible electroporation, $1.0-3.0 \mathrm{kV} / \mathrm{cm}$ enables irreversible permeabilization in plant or animal tissues, and $15-40 \mathrm{kV} / \mathrm{cm}$ is used to inactivate microorganisms. The critical electric field strength depends on the size of the cell, and larger cells require a lower critical electric field strength [9]. PEF technology can be divided into conventional PEF processing (which the pulse duration time is micro to milliseconds) and nanosecond (nsPEF) processing (in which high electric fields are applied for 1-300 ns). The use of nsPEF induces intracellular effects that differ from the pronounced effect of conventional PEF on the cell membrane [10]. The strong electromagnetic field between two electrodes can be used to inactivate microorganisms, perform pasteurization, electroporation, and electropermeabilization [11,12]. Treatment with an electric field results in the formation of local instabilities and pores in microorganism cell membranes (electroporation) [13]. When a biological cell is placed in the area of the external electric field, the ions (positive and negative) that are inside and outside the cell begin to move in the direction of the applied electric field. This leads to the accumulation of oppositely charged electric charges on both sides of the cell membrane. This can cause local increases in pressure, which lead to changes in the thickness of the cell membrane and, consequently, to disruption of its integrity. Breakdown of the membrane occurs when a critical breakdown voltage is reached, causing trans-membrane pore formation [14] (Figure 1). Depending on the electric field applied, electropermeabilization results in cell death or its membrane resealing and a return to the cell's initial condition [15]. The PEF mechanism of action involves pore formation by applying an electric field of sufficiently high strength to cause a potential difference of approx. $0.2 \mathrm{~V}$ across a cell membrane [16,17].

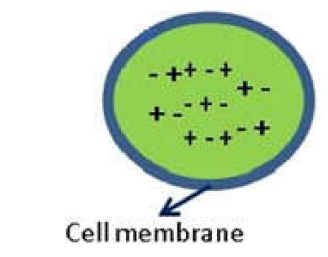

Cell before PEF application

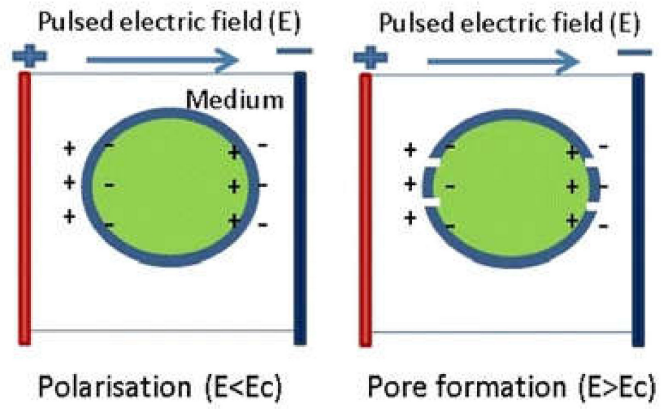

Figure 1. Schematic representation of an electroporation mechanism in a biological cell membrane exposed to an electric field E. Ec-critical electric field strength [14]. 
PEF technology can support conventional processes, or it can be used as a pretreatment. The major methods of lignocellulosic substrates treatment before the methane fermentation process are presented in Table 1.

Table 1. Comparison of the pretreatment methods for enhanced methane production.

\begin{tabular}{|c|c|c|c|c|c|c|}
\hline Method & Pretreatment Type & $\begin{array}{l}\text { Pretreatment } \\
\text { Conditions }\end{array}$ & Biomass & $\begin{array}{l}\text { Methane } \\
\text { Fermentation } \\
\text { Conditions }\end{array}$ & $\begin{array}{c}\text { Increased } \\
\text { Methane Yield (\%) }\end{array}$ & Ref. \\
\hline \multirow[t]{3}{*}{ Physical } & $\begin{array}{l}\text { Mechanical } \\
\text { pulverization }\end{array}$ & $\begin{array}{l}\text { Pulverization, } \\
\text { particle sizes of } \\
33 \text { to } 6 \mathrm{~mm}\end{array}$ & $\begin{array}{l}\text { Sorghum } \\
\text { hybrid }\end{array}$ & $\begin{array}{l}35^{\circ} \mathrm{C} \\
30 \text { days }\end{array}$ & $11-13$ & [18] \\
\hline & $\begin{array}{l}\text { Grinding/ } \\
\text { Milling }\end{array}$ & Mechanical & $\begin{array}{l}\text { Elephant grass, } \\
\text { Mexican } \\
\text { sunflower, } \\
\text { Siam weed }\end{array}$ & $37^{\circ} \mathrm{C}, 30$ days & 22 & [19] \\
\hline & $\begin{array}{l}\text { Hydrodynamic } \\
\text { cavitation }\end{array}$ & $\begin{array}{l}4 \mathrm{~kW}, \\
5 \mathrm{~min}, \\
2800 \mathrm{RPM}\end{array}$ & $\begin{array}{l}\text { Sida } \\
\text { hermaphrodita } \\
\text { silage }\end{array}$ & $\begin{array}{l}37^{\circ} \mathrm{C} \\
40 \text { days }\end{array}$ & 30 & [20] \\
\hline \multirow{2}{*}{$\begin{array}{l}\text { Physico- } \\
\text { chemical }\end{array}$} & Steam explosion & $\begin{array}{l}160^{\circ} \mathrm{C} \text { for } 2 \\
\min \end{array}$ & Corn stover & $\begin{array}{l}37.5^{\circ} \mathrm{C}, \\
49 \text { days }\end{array}$ & 22 & [21] \\
\hline & Hydrothermal & $175^{\circ} \mathrm{C}$ & Napier grass & $\begin{array}{l}35^{\circ} \mathrm{C} \\
42 \text { days }\end{array}$ & 35 & [22] \\
\hline \multirow[t]{3}{*}{ Chemical } & Acid pretreatment & $\begin{array}{l}\text { Dilute } \mathrm{H}_{2} \mathrm{SO}_{4} \\
(1 \%), \\
121^{\circ} \mathrm{C}, \\
10-120 \mathrm{~min}\end{array}$ & Wheat plant & $\begin{array}{l}37^{\circ} \mathrm{C} \\
30 \text { days }\end{array}$ & 15.5 & [23] \\
\hline & Alkali pretreatment & $\begin{array}{l}\mathrm{Ca}(\mathrm{OH})_{2}(7.5 \%), \\
10^{\circ} \mathrm{C}, 20 \mathrm{~h}\end{array}$ & $\begin{array}{l}\text { Maize straw, } \\
\text { grass, sprout } \\
\text { stem }\end{array}$ & $37^{\circ} \mathrm{C}, 30$ days & 37 & [24] \\
\hline & Organic Solvent & $\begin{array}{l}\mathrm{NMMO}, 120^{\circ} \mathrm{C}, \\
3 \mathrm{~h}\end{array}$ & Wheat straw & $37^{\circ} \mathrm{C}, 40$ days & 11 & [25] \\
\hline \multirow{5}{*}{ Biological } & \multirow[t]{2}{*}{$\begin{array}{l}\text { Microbial } \\
\text { consortium }\end{array}$} & \multirow{2}{*}{$\begin{array}{l}\text { Microbial } \\
\text { consortium } \\
\text { TC-5 }\end{array}$} & \multirow[t]{2}{*}{ Wheat straw } & $\begin{array}{l}37^{\circ} \mathrm{C} \\
30 \text { days }\end{array}$ & 22.2 & \multirow[t]{2}{*}{ [26] } \\
\hline & & & & $\begin{array}{l}45^{\circ} \mathrm{C} \\
35 \text { days }\end{array}$ & 36.3 & \\
\hline & \multirow[t]{2}{*}{$\begin{array}{l}\text { Fungal } \\
\text { pretreatment }\end{array}$} & Pleurotus eryngii & Corn stover & $\begin{array}{l}40 \text { days, } \\
30^{\circ} \mathrm{C}\end{array}$ & 19 & [27] \\
\hline & & $\begin{array}{l}\text { Polyporus } \\
\text { brumalis }\end{array}$ & Wheat straw & $36^{\circ} \mathrm{C}, 57$ days & 52 & [28] \\
\hline & $\begin{array}{l}\text { Bacterial } \\
\text { pretreatment }\end{array}$ & Bacillus subtilis & Corn straw & $\begin{array}{l}37^{\circ} \mathrm{C} \\
51 \text { days }\end{array}$ & 17.35 & [29] \\
\hline
\end{tabular}

Applying this technique reduces the process duration and improves its efficiency, thereby reducing the production costs. Pulsed electric field technology can be successfully used to modify existing processes or to develop new, energy-saving, and waste-free technologies for industry [30]. PEF is applied, among others, in food drying [31-34], food preservation $[35,36]$, and inactivation of microorganisms at low temperatures [37].

This study aimed to determine the effect of pretreatment with a pulsed electric field on the biogas potential of maize silage. 


\section{Materials and Methods}

\subsection{Substrate}

Maize silage mixed with water to increase its hydration to $95 \%$ was used as the experimental substrate. The total solids (TS) were $42.62 \%$, and volatile solids (VS) made up $95.80 \%$ of TS (Table 2 ).

Table 2. Characteristics of the maize silage.

\begin{tabular}{ll}
\hline Parameters & Value \\
\hline Hydration [\%] & 57.38 \\
Total solids [\%] & 42.62 \\
Volatile solids [\% TS] & 95.80 \\
Total carbon (TC) [mg C/g TS] & 445.50 \\
Total organic carbon (TOC) [mg C/g TS] & 422.37 \\
Total nitrogen (TN) [mg N/g TS] & 13.42 \\
C/N & 31.47 \\
\hline
\end{tabular}

\subsection{Equipment}

Due to the chopping and pumping system, the construction of the disintegration installation allowed for its operation as a flow-through device, and the application of a separate charging hopper made it possible to use the machine in static conditions (Figure 2).
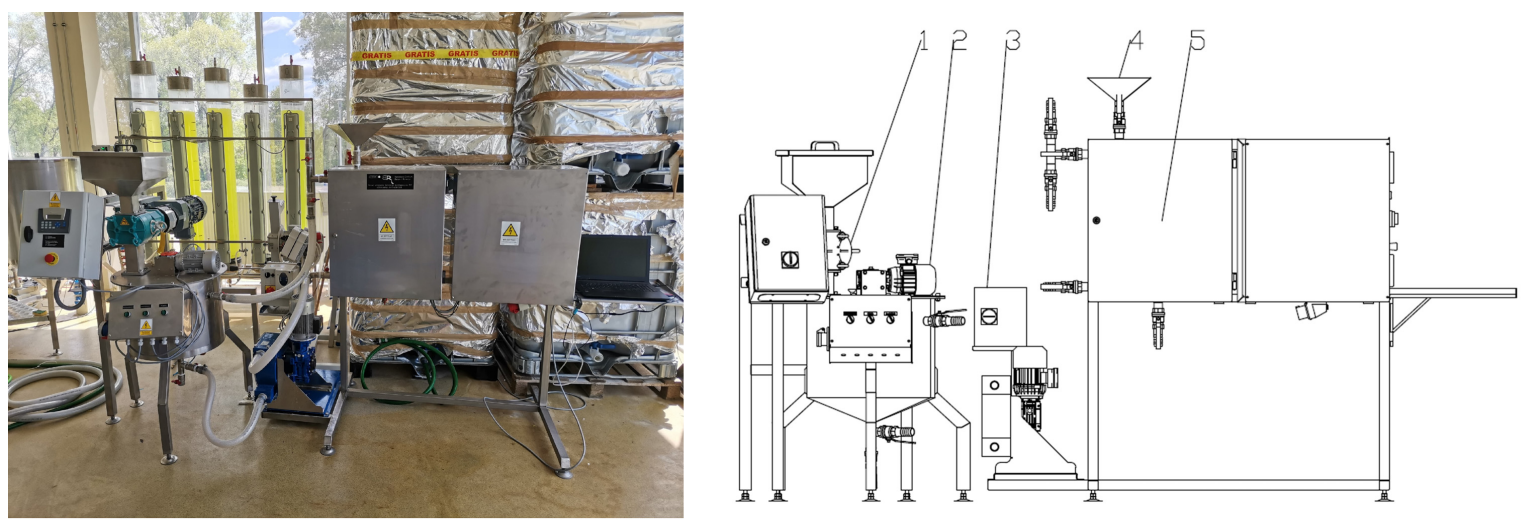

Figure 2. PEF disintegration installation: (1) substrate chopper; (2) substrate container with a stirrer; (3) peristaltic pump for substrate; (4) charging hopper; (5) disintegration chamber cabinet.

The $500 \mathrm{~mL}$ of disintegration chamber had a coaxial construction. The electrodes were separated with an insulator, between which a pulsed electric field was generated by high voltage as electric impulses.

The electrodes were made of stainless steel and the distance between the electrodes was $2 \mathrm{~cm}$. The test stand was equipped with a source of high voltage, which could generate a voltage of $40 \mathrm{kV}$. The device included control and measuring equipment which was used to monitor operating parameters. The PEF disintegration installation was equipped with a charge hopper with a HAL-50 chopper (Börger, Germany), which further homogenized the fibrous experimental material. The stand also included an $80 \mathrm{~L}$ container, into which the chopped experimental material was placed. The material was hydrated up to the appropriate level in the container and the blade stirrer ensured the material homogeneity in the whole volume. The PEF disintegration installation was equipped with an adjustable output peristaltic pump, which fed the substrate to the disintegration chamber. The flow rate regulation was used to change the substrate retention time in the disintegration chamber. The PEF disintegration installation was equipped with a controller responsible for controlling the disintegrator parameters, which, in combination with the software, allowed for the setting of the parameters from the computer level. 


\subsection{Pretreatment}

To prepare the material for the experiment, it was chopped with a chopper, which was part of the PEF disintegration installation. Maize silage hydrated up to the water content of approximately $95 \%$ was used as the study material. The substrate was then poured through the charge hopper into the disintegration chamber and subsequently treated with a pulsed electric field with the following characteristics: voltage, $-40 \mathrm{kV}$; pulse duration, $50 \mu \mathrm{s}$; frequency, $10 \mathrm{kHz}$; pulse shape, rectangular. Due to the coaxial construction, there was a non-uniform field in the chamber. The maximum and minimum electric field in the test cell were $38.61 \mathrm{kV} / \mathrm{cm}$ and $11.66 \mathrm{kV} / \mathrm{cm}$, respectively. The substrate was pretreated at various retention times $(0,30,60,90,120,150,180,210,240$, and $270 \mathrm{~s})$ in the disintegration chamber.

The experiment was performed in three replicates.

\subsection{Determination of Cellulose, Hemicellulose, and Lignin}

The contents of cellulose, hemicellulose, and lignin in the raw substrate and the substrate treated with PEF were determined in a procedure developed by van Soest et al. [38]. The determination involves chemical fractionation with a neutral or acidic detergent. This procedure determined the content of neutral detergent fiber (NDF), acidic detergent fiber (ADF), and acidic detergent lignin (ADL). The cellulose content was calculated as the difference between ADF and ADL, hemicellulose content was calculated as the difference between NDF and ADF, and the lignin content was equal to ADL.

\subsection{Analytical Methods}

The content of glucose, chemical oxygen demand (COD) and total organic carbon (TOC) was determined in the supernatant obtained by centrifuging the raw substrate. Moreover, the content of neutral detergent fibers (NDF), acidic detergent fibers (ADF) and acidic detergent lignin (ADL) was calculated. Similar analyses were performed in the supernatant obtained from samples following disintegration with PEF. Methane fermentation of the samples was conducted in an AMPTS II analyzer to determine the biogas potential. Methane fermentation was performed in $500 \mathrm{~mL}$ reactors. The reactors were equipped with a multi-functional stirring system, which was started every $10 \mathrm{~min}$ and ran for $30 \mathrm{~s}$ at $100 \mathrm{rpm}$. The reactors were inoculated with an anaerobic deposit (I) with the substrate (S) at $200 \mathrm{~mL}$. The ratio of organic matter in the deposit to organic matter in the substrate in the inoculated reactor was I/S $=5$. The reactors were flushed with pure nitrogen to remove oxygen. The fermentation was conducted under mesophilic conditions at $37^{\circ} \mathrm{C}$ for 24 days. The experiment was conducted in three replicates.

The biogas qualitative analysis was carried out in a gas chromatography unit with a thermal conductivity detector (GC-TCD) (Agilent 7890 A). The TS and VS contents were measured by the gravimetric method. The carbon and nitrogen contents in the substrate were determined with Flash 2000 (Thermo). The TOC content was determined with a TOC$\mathrm{L}$ device (Shimadzu). Glucose content was measured with enzymatic tests (Megazyme). The detergent fiber fraction content was determined with ANKOM220 (ANKOM).

The homogeneity of variance was analyzed with a Levene test, and the significance of differences between the variants was analyzed with a Tukey test (HSD). The level of significance was $\alpha=0.05$.

\section{Results and Discussion}

\subsection{Pretreatment Efficiency}

According to the experiment results, the mean initial TOC content was $3260 \pm 147 \mathrm{mg} / \mathrm{L}$. The analyses of the charge subjected to disintegration at the assumed retention times showed that the TOC content was the highest at the pretreatment time of $180 \mathrm{~s}$, while the mean TOC content was $3988 \pm 121 \mathrm{mg} / \mathrm{L}$. The measurements showed that COD in a sample without pretreatment was $8462 \pm 258 \mathrm{mg} \mathrm{O}_{2} / \mathrm{L}$. The highest COD, namely 10,323 $\pm 220 \mathrm{mg} \mathrm{O}_{2} / \mathrm{L}$, was observed with the pretreatment lasting $180 \mathrm{~s}$ (Figure 3). Ki et al. [39] conducted a study of 
the pretreatment of a primary deposit with a pulsed electric field. The analyses showed that pretreatment resulted in a 1.4\% TOC increase compared to the control sample. Salerno et al. [40] applied a pulsed electric field as a method of sludge pretreatment aimed at improvement of methane fermentation. The test results showed that the COD in the filtrate increased by $11.7 \%$ compared to the control sample.

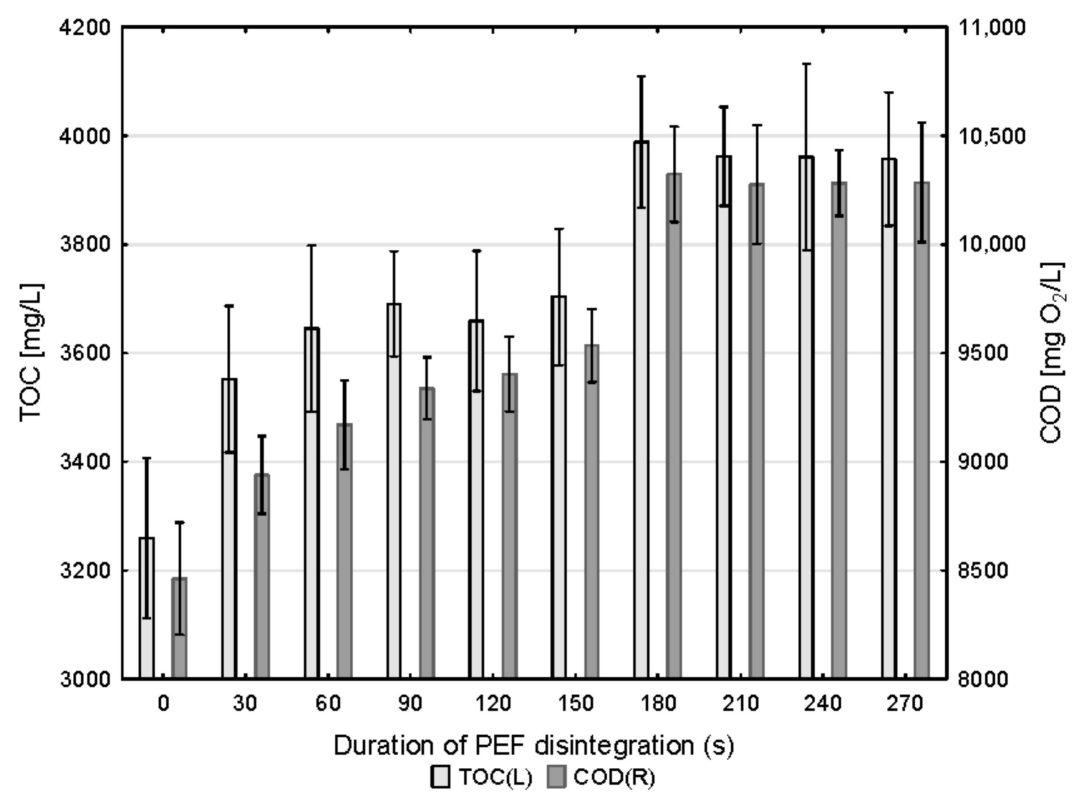

Figure 3. Total organic carbon (TOC) and chemical oxygen demand (COD) content in the liquid phase of the substrate before and after pretreatment.

The tests showed that mean glucose concentration in the liquid phase of the raw substrate was $50.60 \pm 0.77 \mathrm{mg} / \mathrm{g}$ TS. The highest mean glucose concentration $(52.85 \mathrm{mg} / \mathrm{g}$ TS) was observed as a result of disintegration for $180 \mathrm{~s}$. Extending the time of disintegration with PEF did not result in an increase in glucose concentration. The depolymerization effectiveness was also determined by analyzing the content of neutral detergent fibers (NDF), acidic detergent fibers (ADF), and acidic detergent lignin (ADL), which was used as the basis for determination of the cellulose, hemicellulose and lignin content. Analysis of NDF, ADF and ADL showed that cellulose content in the liquid fraction of the non-pretreated substrate was $21.04 \% \mathrm{TS}$, hemicellulose content was $20.02 \%$ TS, and the content of lignin was $3.14 \%$ TS. The analysis of the fiber fraction in pretreated samples showed that the cellulose content in the sample pretreated for $180 \mathrm{~s}$ decreased to $19.5 \%$ TS, hemicellulose decreased to $18.77 \% \mathrm{TS}$, and lignin decreased to $2.68 \%$ TS (Table 3 ).

Table 3. The composition of the substrate before and after pretreatment, and the amount of glucose released to the liquid phase of the substrate.

\begin{tabular}{ccccc}
\hline $\begin{array}{c}\text { Duration of PEF } \\
\text { Pretreatment (s) }\end{array}$ & $\begin{array}{c}\text { Cellulose } \\
\text { (\% TS) }\end{array}$ & $\begin{array}{c}\text { Lignin } \\
\text { (\% TS) }\end{array}$ & $\begin{array}{c}\text { Hemicellulose } \\
\text { (\% TS) }\end{array}$ & $\begin{array}{c}\text { Glucose Yield } \\
\text { (mg/g TS) }\end{array}$ \\
\hline 0 (control) & $21.04 \pm 0.78$ & $20.02 \pm 0.51$ & $3.14 \pm 0.09$ & $50.60 \pm 0.77$ \\
30 & $20.07 \pm 0.36$ & $20.27 \pm 0.65$ & $3.10 \pm 0.35$ & $51.42 \pm 0.25$ \\
60 & $19.91 \pm 1.90$ & $19.87 \pm 0.66$ & $2.95 \pm 0.20$ & $51.45 \pm 0.46$ \\
90 & $20.06 \pm 0.76$ & $19.79 \pm 0.75$ & $3.07 \pm 0.36$ & $51.11 \pm 0.33$ \\
120 & $19.69 \pm 0.57$ & $19.74 \pm 0.67$ & $3.17 \pm 0.29$ & $51.57 \pm 0.65$ \\
150 & $19.68 \pm 0.70$ & $19.48 \pm 0.28$ & $2.94 \pm 0.06$ & $52.18 \pm 0.31$ \\
180 & $19.50 \pm 0.87$ & $18.77 \pm 0.36$ & $2.68 \pm 0.23$ & $52.85 \pm 0.26$ \\
210 & $19.55 \pm 0.76$ & $19.22 \pm 0.48$ & $2.85 \pm 0.14$ & $52.79 \pm 0.32$ \\
240 & $19.58 \pm 0.80$ & $19.26 \pm 0.60$ & $2.88 \pm 0.03$ & $52.76 \pm 0.31$ \\
270 & $19.62 \pm 0.76$ & $19.36 \pm 0.45$ & $2.86 \pm 0.11$ & $52.78 \pm 0.22$ \\
\hline
\end{tabular}




\subsection{Methane Production}

The biogas potential analysis showed that the mean biogas production rate was $659.6 \mathrm{~mL} / \mathrm{g}$ VS in the non-pretreated sample. The highest biogas production output was achieved in the pretreated sample at the retention time of $180 \mathrm{~s}(751.97 \mathrm{~mL} / \mathrm{g}$ VS), which resulted in an increase of approximately $14 \%$. The methane production rate for the control sample was $401.83 \mathrm{~mL} \mathrm{CH}_{4} / \mathrm{g}$ VS and it was $465.62 \mathrm{~mL} \mathrm{CH}_{4} / \mathrm{g}$ VS for the sample following disintegration (Figure 4).

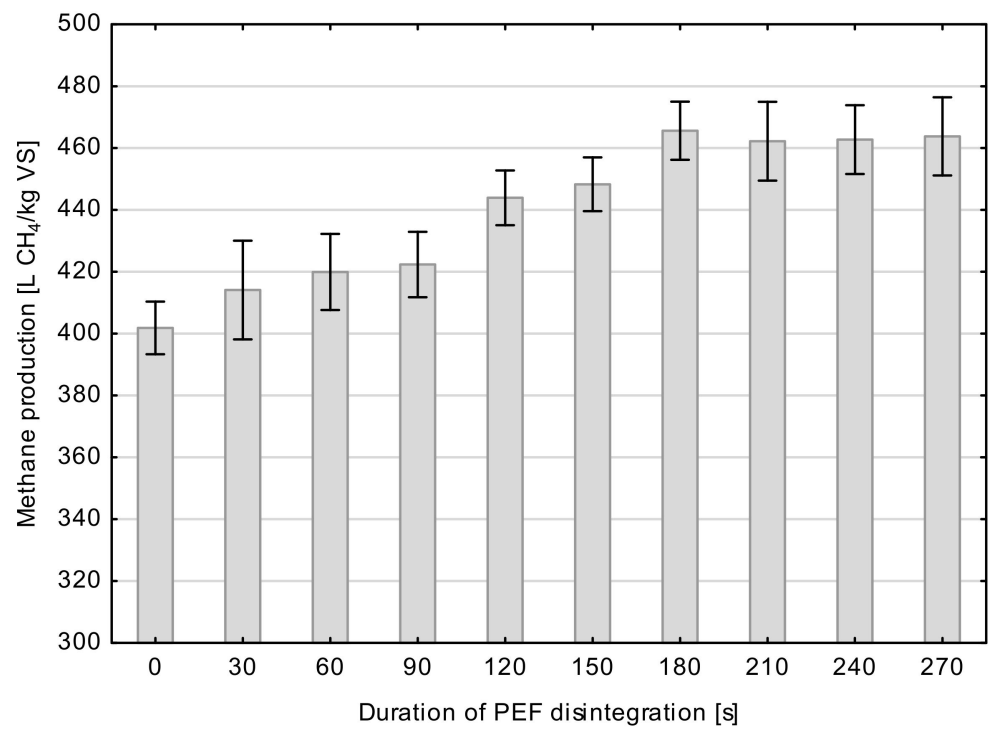

Figure 4. Methane production from the pretreated substrate with a pulsed electric field.

The qualitative analysis of biogas showed that it contained $60.92-62.11 \%$ of methane. Lindmark et al. [41] analyzed the effect of pretreatment by a pulsed electric field on the biogas production output from ley crop silage. Their findings showed that biogas production can be increased by $16 \%$ when a field with a strength of $96 \mathrm{kV} / \mathrm{cm}$ is used. However, the study did not reveal any effect on methane content in biogas, which was $60 \%$ on average. Kovačić et al. [42] examined the effect of electroporation on biogas production increases in the methane fermentation of post-harvest waste, such as maize straw, soy straw and sunflower straw. Those experiments showed that co-fermentation of cattle manure with substrate following electroporation at the voltage of 200-365 V resulted in biogas formation at a level of $456.22 \mathrm{~mL} / \mathrm{g}$ VS and $402.22 \mathrm{~mL} / \mathrm{g} \mathrm{VS}$, for maize straw and soy straw, respectively. Methane production output was $280.80 \mathrm{~mL} \mathrm{CH}_{4} / \mathrm{g}$ VS and $257.34 \mathrm{~mL} \mathrm{CH}_{4} / \mathrm{g}$ VS, respectively, which was $13 \%$ and $17 \%$ higher than in the control sample. Safavi and Unnthorsson [43] conducted a study to determine the effect of a pulsed electric field on methane production from leachate. By pretreatment with an electric field with a strength of $20 \mathrm{kV} / \mathrm{cm}$ and a frequency of $1.7 \mathrm{~Hz}$, they increased methane production by $44 \%$. Lee and Rittmann [44] conducted a study on the effect of pretreatment with PEF of active sludge on anaerobic fermentation. Pretreatment with PEF resulted in a methane production output increase of up to $33 \%$. Wang et al. [45] studied the effect of treatment with a high voltage pulsed electric field on the biogas production rate in anaerobic fermentation of hybrid Pennisetum. They showed that disintegration with an electric field of $15 \mathrm{kV} / 120 \mathrm{~Hz}$ increased accumulated biogas production output over 32 days by $26.95 \%$ compared to the control sample.

Based on the obtained results, an energy calculation of the produced biogas was carried out (Table 4). The increase in energy due to PEF disintegration was calculated by multiplying the increase in methane productivity relative to the control sample and the calorific value of methane. The energy input was a real energy consumption of PEF 
disintegrator. The energy gain value was calculated as the difference between increase in energy due to PEF disintegration and energy input.

Table 4. Calculation of the energy efficiency of the PEF disintegration of biomass.

\begin{tabular}{cccc}
\hline Disintegration Time (s) & $\begin{array}{c}\text { Energy Input } \\
\text { (Wh/gTS) }\end{array}$ & $\begin{array}{c}\text { Increase in Energy due } \\
\text { to PEF Disintegration }\end{array}$ & $\begin{array}{c}\text { Energy Gain } \\
\text { (Wh/g TS) }\end{array}$ \\
\hline 0 & - & - & - \\
30 & $0.058 \pm 0.005$ & $0.113 \pm 0.068$ & $0.054 \pm 0.068$ \\
60 & $0.117 \pm 0.005$ & $0.166 \pm 0.035$ & $0.049 \pm 0.036$ \\
90 & $0.175 \pm 0.007$ & $0.188 \pm 0.019$ & $0.013 \pm 0.019$ \\
120 & $0.233 \pm 0.009$ & $0.386 \pm 0.031$ & $0.153 \pm 0.031$ \\
150 & $0.292 \pm 0.006$ & $0.426 \pm 0.018$ & $0.135 \pm 0.018$ \\
180 & $0.350 \pm 0.006$ & $0.585 \pm 0.009$ & $0.235 \pm 0.009$ \\
210 & $0.408 \pm 0.005$ & $0.554 \pm 0.043$ & $0.146 \pm 0.044$ \\
270 & $0.467 \pm 0.005$ & $0.559 \pm 0.029$ & $0.092 \pm 0.029$ \\
\hline
\end{tabular}

This analysis proved that the energy gain was obtained for each tested PEF disintegration time. The highest energy gain was obtained in the pretreated sample at the retention time of $180 \mathrm{~s}(0.235 \mathrm{Wh} / \mathrm{g}$ TS). A further increase in the disintegration time resulted in a decrease in energy gain, resulting from an increase in energy input and the lack of increase in methane production. Zieliński et al. [20] used hydrodynamic cavitation for the pretreatment of Sida hermaphrodita silage. They obtained an energy gain of $0.17 \mathrm{Wh} / \mathrm{g}$ TS with an input energy of $0.28 \mathrm{Wh} / \mathrm{g}$ TS. These results are similar to those results presented in the present article.

\section{Conclusions}

Lignocellulosic substrates demonstrate high potential for methane production, but their complex structure limits their use in methane fermentation processes. Thus, pretreatment is a necessary for the efficient utilization of this type of biomass.

The use of a pulsed electric field may be an effective way to improve the substrate-tobiogas conversion rate in methane fermentation of maize silage.

Compared with the control sample, the nine PEF pretreated experimental samples displayed higher methane productivity in anaerobic digestion. The best effects of treatment with a PEF were observed at $20 \mathrm{kV} / \mathrm{cm} / 10 \mathrm{kHz} / 180 \mathrm{~s}$, in which biogas production output reached $751.97 \mathrm{~mL} / \mathrm{g} \mathrm{VS}$, which was approximately $14 \%$ higher than in the control sample. Methane productivity under such conditions was $465.62 \mathrm{~mL} \mathrm{CH}_{4} / \mathrm{g}$ VS; i.e., it was $16 \%$ higher compared with the control sample. The analysis of energy efficiency showed that the application of PEF disintegration with a time retention of $180 \mathrm{~s}$ generates an energy gain of $0.235 \mathrm{Wh} / \mathrm{g}$ TS.

Author Contributions: Conceptualization, D.S.; funding acquisition, D.S.; investigation, D.S. and K.S.; supervision, D.S. and K.S.; visualization, D.S. and K.S.; writing—original draft, D.S. and K.S.; writing - review and editing, D.S. All authors have read and agreed to the published version of the manuscript.

Funding: The study was part of the project "Development a lignocellulose biomass disintegration technology using a pulsed electric field" as part of the LIDER IX programme, financed by the National Centre for Research and Development No. LIDER/8/0026/L-9/17/NCBR/2018. Co-financing amount: PLN 1,166,250.00.

Institutional Review Board Statement: Not applicable.

Informed Consent Statement: Not applicable.

Data Availability Statement: Data sharing not applicable.

Conflicts of Interest: The authors declare no conflict of interest. 


\section{References}

1. Wang, C.; Zhang, X.; Liu, Q.; Zhang, Q.; Chen, L.; Ma, L. A review of conversion of lignocellulose biomass to liquid transport fuels by integrated refining strategies. Fuel Process. Technol. 2020, 208, 106485. [CrossRef]

2. Gupta, V.K.; Kubicek, C.P.; Berrin, J.G.; Wilson, D.W.; Couturier, M.; Berlin, A.; Filho, E.X.F.; Ezeji, T. Fungal Enzymes for Bio-Products from Sustainable and Waste Biomass. Trends Biochem. Sci. 2016, 41, 633-645. [CrossRef]

3. Chen, D.; Gao, A.; Cen, K.; Zhang, J.; Cao, X.; Ma, Z. Investigation of biomass torrefaction based on three major components: Hemicellulose, cellulose, and lignin. Energy Convers. Manag. 2018, 169, 228-237. [CrossRef]

4. Anwar, Z.; Gulfraz, M.; Irshad, M. Agro-industrial lignocellulosic biomass a key to unlock the future bio-energy: A brief review. J. Radiat. Res. Appl. Sci. 2014, 7, 163-173. [CrossRef]

5. Arora, A.; Nandal, P.; Singh, J.; Verma, M.L. Nanobiotechnological advancements in lignocellulosic biomass pretreatment. Mater. Sci. Energy Technol. 2020, 3, 308-318. [CrossRef]

6. Lebovka, N.I.; Kupchik, M.P.; Sereda, K.; Vorobiev, E. Electrostimulated thermal permeabilisation of potato tissues. Biosyst. Eng. 2008, 99, 76-80. [CrossRef]

7. Kotnik, T.; Frey, W.; Sack, M.; Haberl Meglič, S.; Peterka, M.; Miklavčič, D. Electroporation-based applications in biotechnology. Trends Biotechnol. 2015, 33, 480-488. [CrossRef]

8. Puértolas, E.; Barba, F.J. Electrotechnologies applied to valorization of by-products from food industry: Main findings, energy and economic cost of their industrialization. Food Bioprod. Process. 2016, 100, 172-184. [CrossRef]

9. Raso, J.; Frey, W.; Ferrari, G.; Pataro, G.; Knorr, D.; Teissie, J.; Miklavčič, D. Recommendations guidelines on the key information to be reported in studies of application of PEF technology in food and biotechnological processes. Innov. Food Sci. Emerg. Technol. 2016, 37, 312-321. [CrossRef]

10. Buchmann, L.; Mathys, A. Perspective on Pulsed Electric Field Treatment in the Bio-based Industry. Front. Bioeng. Biotechnol. 2019, 7, 265. [CrossRef]

11. González-Arenzana, L.; Portu, J.; López, R.; López, N.; Santamaría, P.; Garde-Cerdán, T.; López-Alfaro, I. Inactivation of wine-associated microbiota by continuous pulsed electric field treatments. Innov. Food Sci. Emerg. Technol. 2015, 29, 187-192. [CrossRef]

12. Timmermans, R.A.H.; Nierop Groot, M.N.; Nederhoff, A.L.; van Boekel, M.A.J.S.; Matser, A.M.; Mastwijk, H.C. Pulsed electric field processing of different fruit juices: Impact of $\mathrm{pH}$ and temperature on inactivation of spoilage and pathogenic micro-organisms. Int. J. Food Microbiol. 2014, 173, 105-111. [CrossRef]

13. Kotnik, T. Lightning-triggered electroporation and electrofusion as possible contributors to natural horizontal gene transfer. Phys. Life Rev. 2013, 10, 351-370. [CrossRef]

14. Kumari, B.; Tiwari, B.K.; Hossain, M.B.; Brunton, N.P.; Rai, D.K. Recent Advances on Application of Ultrasound and Pulsed Electric Field Technologies in the Extraction of Bioactives from Agro-Industrial By-products. Food Bioprocess Technol. 2018, 11, 223-241. [CrossRef]

15. Teissie, J.; Golzio, M.; Rols, M.P. Mechanisms of cell membrane electropermeabilization: A minireview of our present (lack of?) knowledge. Biochim. Biophys. Acta Gen. Subj. 2005, 1724, 270-280. [CrossRef]

16. Teissié, J.; Eynard, N.; Gabriel, B.; Rols, M.P. Electropermeabilization of cell membranes. Adv. Drug Deliv. Rev. 1999, 35, 3-19. [CrossRef]

17. Dellarosa, N.; Tappi, S.; Ragni, L.; Laghi, L.; Rocculi, P.; Dalla Rosa, M. Metabolic response of fresh-cut apples induced by pulsed electric fields. Innov. Food Sci. Emerg. Technol. 2016, 38, 356-364. [CrossRef]

18. Herrmann, C.; Heiermann, M.; Idler, C.; Prochnow, A. Particle Size Reduction during Harvesting of Crop Feedstock for Biogas Production I: Effects on Ensiling Process and Methane Yields. Bioenergy Res. 2012, 5, 926-936. [CrossRef]

19. Dahunsi, S.O. Mechanical pretreatment of lignocelluloses for enhanced biogas production: Methane yield prediction from biomass structural components. Bioresour. Technol. 2019, 280, 18-26. [CrossRef]

20. Zielinski, M.; Rusanowska, P.; Krzywik, A.; Dudek, M.; Nowicka, A.; Ebowski, M.D. Application of hydrodynamic cavitation for improving methane fermentation of sida hermaphrodita silage. Energies 2019, 12, 526. [CrossRef]

21. Lizasoain, J.; Trulea, A.; Gittinger, J.; Kral, I.; Piringer, G.; Schedl, A.; Nilsen, P.J.; Potthast, A.; Gronauer, A.; Bauer, A. Corn stover for biogas production: Effect of steam explosion pretreatment on the gas yields and on the biodegradation kinetics of the primary structural compounds. Bioresour. Technol. 2017, 244, 949-956. [CrossRef]

22. Phuttaro, C.; Sawatdeenarunat, C.; Surendra, K.C.; Boonsawang, P.; Chaiprapat, S.; Khanal, S.K. Anaerobic digestion of hydrothermally-pretreated lignocellulosic biomass: Influence of pretreatment temperatures, inhibitors and soluble organics on methane yield. Bioresour. Technol. 2019, 284, 128-138. [CrossRef] [PubMed]

23. Taherdanak, M.; Zilouei, H.; Karimi, K. The influence of dilute sulfuric acid pretreatment on biogas production form wheat plant. Int. J. Green Energy 2016, 13, 1129-1134. [CrossRef]

24. Khor, W.C.; Rabaey, K.; Vervaeren, H. Low temperature calcium hydroxide treatment enhances anaerobic methane production from (extruded) biomass. Bioresour. Technol. 2015, 176, 181-188. [CrossRef] [PubMed]

25. Mancini, G.; Papirio, S.; Lens, P.N.L.; Esposito, G. Increased biogas production from wheat straw by chemical pretreatments. Renew. Energy 2018, 119, 608-614. [CrossRef]

26. Kong, X.; Du, J.; Ye, X.; Xi, Y.; Jin, H.; Zhang, M.; Guo, D. Enhanced methane production from wheat straw with the assistance of lignocellulolytic microbial consortium TC-5. Bioresour. Technol. 2018, 263, 33-39. [CrossRef] 
27. Wyman, V.; Henríquez, J.; Palma, C.; Carvajal, A. Lignocellulosic waste valorisation strategy through enzyme and biogas production. Bioresour. Technol. 2018, 247, 402-411. [CrossRef]

28. Rouches, E.; Zhou, S.; Sergent, M.; Raouche, S.; Carrere, H. Influence of white-rot fungus Polyporus brumalis BRFM 985 culture conditions on the pretreatment efficiency for anaerobic digestion of wheat straw. Biomass Bioenergy 2018, 110, 75-79. [CrossRef]

29. Xu, W.; Fu, S.; Yang, Z.; Lu, J.; Guo, R. Improved methane production from corn straw by microaerobic pretreatment with a pure bacteria system. Bioresour. Technol. 2018, 259, 18-23. [CrossRef]

30. Mahnič-Kalamiza, S.; Vorobiev, E.; Miklavčič, D. Electroporation in Food Processing and Biorefinery. J. Membr. Biol. 2014, 247, 1279-1304. [CrossRef]

31. Ostermeier, R.; Giersemehl, P.; Siemer, C.; Töpfl, S.; Jäger, H. Influence of pulsed electric field (PEF) pre-treatment on the convective drying kinetics of onions. J. Food Eng. 2018, 237, 110-117. [CrossRef]

32. Wiktor, A.; Nowacka, M.; Dadan, M.; Rybak, K.; Lojkowski, W.; Chudoba, T.; Witrowa-Rajchert, D. The effect of pulsed electric field on drying kinetics, color, and microstructure of carrot. Dry. Technol. 2016, 34, 1286-1296. [CrossRef]

33. Huang, W.; Feng, Z.; Aila, R.; Hou, Y.; Carne, A.; Bekhit, A.E.D.A. Effect of pulsed electric fields (PEF) on physico-chemical properties, $\beta$-carotene and antioxidant activity of air-dried apricots. Food Chem. 2019, 291, 253-262. [CrossRef] [PubMed]

34. Onwude, D.I.; Hashim, N.; Janius, R.; Abdan, K.; Chen, G.; Oladejo, A.O. Non-thermal hybrid drying of fruits and vegetables: A review of current technologies. Innov. Food Sci. Emerg. Technol. 2017, 43, 223-238. [CrossRef]

35. Hartyáni, P.; Dalmadi, I.; Cserhalmi, Z.; Kántor, D.B.; Tóth-Markus, M.; Sass-Kiss, Á. Physical-chemical and sensory properties of pulsed electric field and high hydrostatic pressure treated citrus juices. Innov. Food Sci. Emerg. Technol. 2011, 12, 255-260. [CrossRef]

36. Vervoort, L.; van der Plancken, I.; Grauwet, T.; Timmermans, R.A.H.; Mastwijk, H.C.; Matser, A.M.; Hendrickx, M.E.; van Loey, A. Comparing equivalent thermal, high pressure and pulsed electric field processes for mild pasteurization of orange juice: Part II: Impact on specific chemical and biochemical quality parameters. Innov. Food Sci. Emerg. Technol. 2011, 12, 466-477. [CrossRef]

37. González-Arenzana, L.; López-Alfaro, I.; Garde-Cerdán, T.; Portu, J.; López, R.; Santamaría, P. Microbial inactivation and MLF performances of Tempranillo Rioja wines treated with PEF after alcoholic fermentation. Int. J. Food Microbiol. 2018, 269, 19-26. [CrossRef]

38. van Soest, P.J.; Robertson, J.B.; Lewis, B.A. Methods for Dietary Fiber, Neutral Detergent Fiber, and Nonstarch Polysaccharides in Relation to Animal Nutrition. J. Dairy Sci. 1991, 74, 3583-3597. [CrossRef]

39. Ki, D.; Parameswaran, P.; Rittmann, B.E.; Torres, C.I. Effect of pulsed electric field pretreatment on primary sludge for enhanced bioavailability and energy capture. Environ. Eng. Sci. 2015, 32, 831-837. [CrossRef]

40. Salerno, M.B.; Lee, H.-S.; Parameswaran, P.; Rittmann, B.E. Using a Pulsed Electric Field as a Pretreatment for Improved Biosolids Digestion and Methanogenesis. Proc. Water Environ. Fed. 2012, 2008, 2005-2018. [CrossRef]

41. Lindmark, J.; Lagerkvist, A.; Nilsson, E.; Carlsson, M.; Thorin, E.; Dahlquist, E.; Lindmark, J.; Nilsson, E.; Thorin, E.; Dahlquist, E.; et al. Evaluating the Effects of Electroporation Pre-treatment on the Biogas Yield from Ley Crop Silage. Appl. Biochem. Biotechnol. 2014, 174, 2616-2625. [CrossRef]

42. Đurđica, K.; Davor, K.; Slavko, R.; Daria, J.; Robert, S.; Marina, T. Electroporation of harvest residues for enhanced biogas production in anaerobic co-digestion with dairy cow manure. Bioresour. Technol. 2019, 274, 215-224.

43. Safavi, S.M.; Unnthorsson, R. Methane yield enhancement via electroporation of organic waste. Waste Manag. 2017, 66, 61-69. [CrossRef]

44. Lee, I.S.; Rittmann, B.E. Effect of low solids retention time and focused pulsed pre-treatment on anaerobic digestion of waste activated sludge. Bioresour. Technol. 2011, 102, 2542-2548. [CrossRef]

45. Wang, B.; Chen, T.; Qin, X.; Wu, Q.; Zhao, Y.; Bai, S.; Peng, W.; Feng, B. Effect of high-voltage pulsed electric field (HPEF) pretreatment on biogas production rates of hybrid Pennisetum by anaerobic fermentation. Nat. Gas Ind. B 2018, 5, 48-53. [CrossRef] 